\title{
Rodents as potential hosts and reservoirs of parasites along the edge of a Central African forest: Bwindi impenetrable national park, South Western Uganda
}

\author{
Patrick Mawanda ${ }^{1}$, Innocent Rwego ${ }^{2,3}$, John J Kisakye ${ }^{2}$, Douglas Sheil ${ }^{4}$
}

1. Makerere University, College of Education and External Studies, School of Distance and Lifelong studies, Department of distance education. P. O. Box 7062, Kampala, Uganda.

2. Makerere University, College of Natural Sciences, Department of Biological Sciences, P. O. Box 7062, Kampala, Uganda.

3. College of Veterinary Medicine, One Health Division, University of Minnesota, St. Paul, 1954 Buford Avenue, MN 55108, USA

4. Department of Ecology and Natural Resource Management, Norwegian University of Life Sciences, P. O. Box 5003 NO-1432 Ås, Norway. Center for International Forestry Research (CIFOR), GPO Box 113 BOCBD, Bogor 1600, Indonesia. Institute of Tropical Forest Conservation, P. O. Box 44, Kabale, Uganda.

\section{Emails:}

Innocent Rwego: irwego@umn.edu; John J Kisakye: jjmkisakye@yahoo.com; Douglas Sheil: douglas.sheil@nmbu.no

\begin{abstract}
Background: Rodents which constitute $42 \%$ of the world's mammalian population are major reservoirs of pathogens that cause zoonoses. Currently we know little about rodents' potential zoonotic transfer from human settlements into protected areas and how any such threats might be reduced.

Objective: To investigate the role of rodents as reservoirs of zoonotic pathogens along the boundary of Bwindi.

Methods: A rodent inventory in three villages along the edge of Bwindi, was carried using live trapping techniques and the local rodents' ecto and endoparasite fauna investigated.

Results: Two hundred eighty eight rodents captured belonged to 24 species, 17 genera and 4 families with Lophuromys aquilus being most abundant (30.2\%). 240 ectoparasites which included mites, fleas and ticks were collected from 88 rodents out of 249. Proamys jacksoni rodents were most infested. Although the mites represented the largest proportion (84.6\%), the highest species diversity was shown among the fleas (9 species). Some $36.9 \%$ of the rodents were infected with endoparasites of which L. aquilus haboured most. Endoparasitic genera identified included Nippostrongylus, Ascaris, Strongyloides, Trichuris, Hymenolepis, Taenia and Cryptosporidium.

Conclusion: Rodents have a zoonotic potentiality. There is need for developing effective integrated rodent management programs against rodent to reduce chances of parasite transmission within the protected areas.
\end{abstract}

Keywords: Bwind, human disease, mountain gorillas, rodents, transmission.

DOI: https://dx.doi.org/10.4314/ahs.v20i3.20

Cite as: Mawanda P, Rwego I, Kisakye JJ, Sheil D. Rodents as potential hosts and reservoirs of parasites along the edge of a Central African forest: Bwindi impenetrable national park, South Western Uganda. Afri Health Sci. 2020;20(3): 1168-1178. https:// dx.doi.org/10.4314/abs.v20i3.20

\section{Corresponding author:}

Patrick Mawanda,

Makerere University, College of Education

and External Studies, School of Distance

and Life long studies,

Department of distance education.

P. O. Box 7062, Kampala, Uganda.

Mobile: +256 $774458932 /+256704300727$

E-mail: mawpat44@yahoo.com /

mawpat44@gmail.com

\section{Introduction}

About $70 \%$ of emerging infectious diseases implicate vectors and reservoirs in their transmission cycle ${ }^{1}$. Vectors include insects and acarines, while many mammalian taxa can act as reservoirs. Rodents which constitute $42 \%$ of the world's mammalian population ${ }^{2}$ are major reservoirs of pathogens that cause zoonoses and have played a central role in many major epidemics ${ }^{3}$.

The importance of rodents in the spread of zoonoses is a reflection of their ecology. Rodents are present in all biotopes worldwide; being able to breed rapidly, eat work is properly cited.
} 
a wide variety of food and adapt to fast environmental changes ${ }^{4}$. This flexibility has made rodents efficient hosts to many ectoparasites, majority of which are vectors of socio-economically important pathogens.

Rodents can transmit infectious agents from natural to modified environments in various ways ${ }^{3}$; horizontally to other rodents living close to anthropised environments ${ }^{5}$, as reservoirs on which intermediate vectors feed and get infected before transmitting the infectious organisms to humans and other animals ${ }^{6}$ and from anthropised areas to wild animals ${ }^{3}$. Rodents are not only infected by potential zoonotic helminthes (Trichuria and Hymenolepis sp) and coccidian protozoa ${ }^{7}$ but also known to transmit human and animal diseases such as Leptospira spp, Borrelia spp., Yersinia pestis and Bartonella $s p p^{8}$. The humans contract Leptosporosis through direct contact with urine or sometimes the environment contaminated with urine containing leptospires ${ }^{8}$. Even though Borrelia species has no known animal species as reservoirs, B. duttonii was found to be maintained in rodents ${ }^{9-11}$. Rodents are thought to be reservoirs for Yersinia pestis that causes plague, a disease that has affected humans in West Nile, Uganda ${ }^{6}$.

The nature and frequency of human contact with wildlife, rodents inclusive, is increasing as a result of hunting, human encroachment on wildlife habitats, research, ecotourism, and other activities that bring people and wildlife into close proximity or direct contact ${ }^{12}$. People surrounding Bwindi are subsistence farmers who supplement their meager existence from the forest resource utilisation zones ${ }^{13}$. Within the communities are specialist user groups with interests such as beekeeping, traditional medicines, basketry, pit-sawing, game hunting, fishing and gold mining. Of particular note are the Batwa, a marginalised indigenous group of hunter-gatherers who now squat near the boarder of the park ${ }^{14}$.

Wildlife including rodents move across the park boundary venturing into areas used by humans and thus come into direct or indirect contact with people along the park margin and their livestock ${ }^{15}$. Conversely, animals in the park interact with the field assistants and tourists who later interact with local community. All such interactions have potential for permitting anthroponotic and zoonotic pathogen transmission and thus modify the threat of disease to animals and people ${ }^{16}$. Of particular concern are Bwindi's gorillas and chimpanzees as these are susceptible to many human pathogens and are known to have been killed by exposure in the past ${ }^{17}$.
Any such exposure increases the threat to these already vulnerable populations.

As the interaction between humans and wildlife increases, the importance of surveillance for emerging diseases cannot be overstated. This study examined the species composition of rodents along Bwindi boundary and their associated parasites to avail information on possible endoparasites causing zoonoses and ectoparasites which are potential vectors of agents that cause zoonoses.

\section{Materials and methods}

The study was conducted in and around Bwindi - a $331 \mathrm{~km}^{2}$ area of mountain forest in SW Uganda. Sampling was carried out in Ruhija, Nkuringo and Buhoma. These villages are distributed in a range of different elevations (2350, 2161 and 1500 metres respectively), an aspect that dictates upon the vegetation type present and in turn their rodent species composition.

Using live trapping with Sharman and Tomahawk traps, rodents were sampled across two categories of anthropogenic disturbance in each village: i.e. locations where the forest was contiguous with an agricultural land (Site 1) and close to human residential areas (Site 2). In each village, a $200 \mathrm{~m}$ diameter trap web, with four transects, each constituting 20 trap stations $10 \mathrm{~m}$ apart, was set up in each site. At each trap station, a Sharman trap was laid and then a Tomahawk trap placed after every two stations; resulting into 80 Sharman and 40 Tomahawk traps per trap web. Traps were placed both on the ground and in the branches of trees, following the methods used by Kityo ${ }^{18}$, baited between 15:00 and 17:00 hours with a combination of sweet bananas, maize flour and roasted ground nuts left to ferment.

Traps were inspected daily initially for nine days, both early in the morning for nocturnal species and late in the evening for diurnal species resulting into a trap effort of 960 and 1920 trap nights per site and village respectively.

Each rodent captured was removed from the trap and measured (head-body, tail, ear and hind foot lengths). These measurements plus the pelage were used to identify the rodents to species level using keys prepared by Wilson and Reeder ${ }^{2}$. For each rodent, ectoparasites were collected following the methods of Iaunbauere \& Spungis, and Kia et al ${ }^{19,20}$. Ectoparasites were pre- 
served in vials containing $0.5 \mathrm{ml}$ of $95 \%$ ethanol and stored at room temperature, as advised by USAID PREDICT ${ }^{21}$ for subsequent identification. About 200 $\mathrm{mg}$ of fresh faeces from each rodent were placed in a $0.1 \mathrm{ml}$ cryovial containing $10 \%$ formalin for further processing to identify endoparasites. Faecal samples were concentrated using the Formol-ether concentration technique, thereafter processed and microscopically examined using the protocols described by Dryden et $\mathrm{al}^{22}$ to diagnose Giardia, Entamoeba cysts, helminthes eggs. Cryptosporidium oocysts were diagnosed using Ziehl-Neelsen staining technique.

Parasite prevalence was quantified as the number of individuals of a particular species infested or infected with parasites divided by the total number of individuals of that species and expressed as a percentage. Using the method of Marshall ${ }^{23}$, the specific indices (number of ectoparasites of a particular species in a particular host species multiplied by 100 and divided by the sum of the number of ectoparasites of that species in all host species) were computed to determine host preference among the ectoparasites. Difference in the abundance of rodents and ectoparasites within the different study sites and villages was tested using Kruskal Wallis tests. Permission to conduct this study was sought from Uganda Wildlife Authority and Uganda National Council of Science and Technology.

\section{Results}

A total of 288 rodents belonging to 24 species from 17 genera and 4 families were recorded from domestic, peridomestic and sylvatic environments. Family Muridae dominated with 21 species accounting for $87.5 \%$ of all the species recorded while the other families, Cricetidae, Nesomyidae and Myoxidae had one species each. The majority of the rodent species $(41.7 \%)$ were captured from peridomestic environments while 20.8 and $4.2 \%$ from sylvatic and domestic respectively (Fig 2). Approximately $16.7 \%$ were captured from all the three environment categories.

A total of 240 ectoparasites were collected from 88 ro-

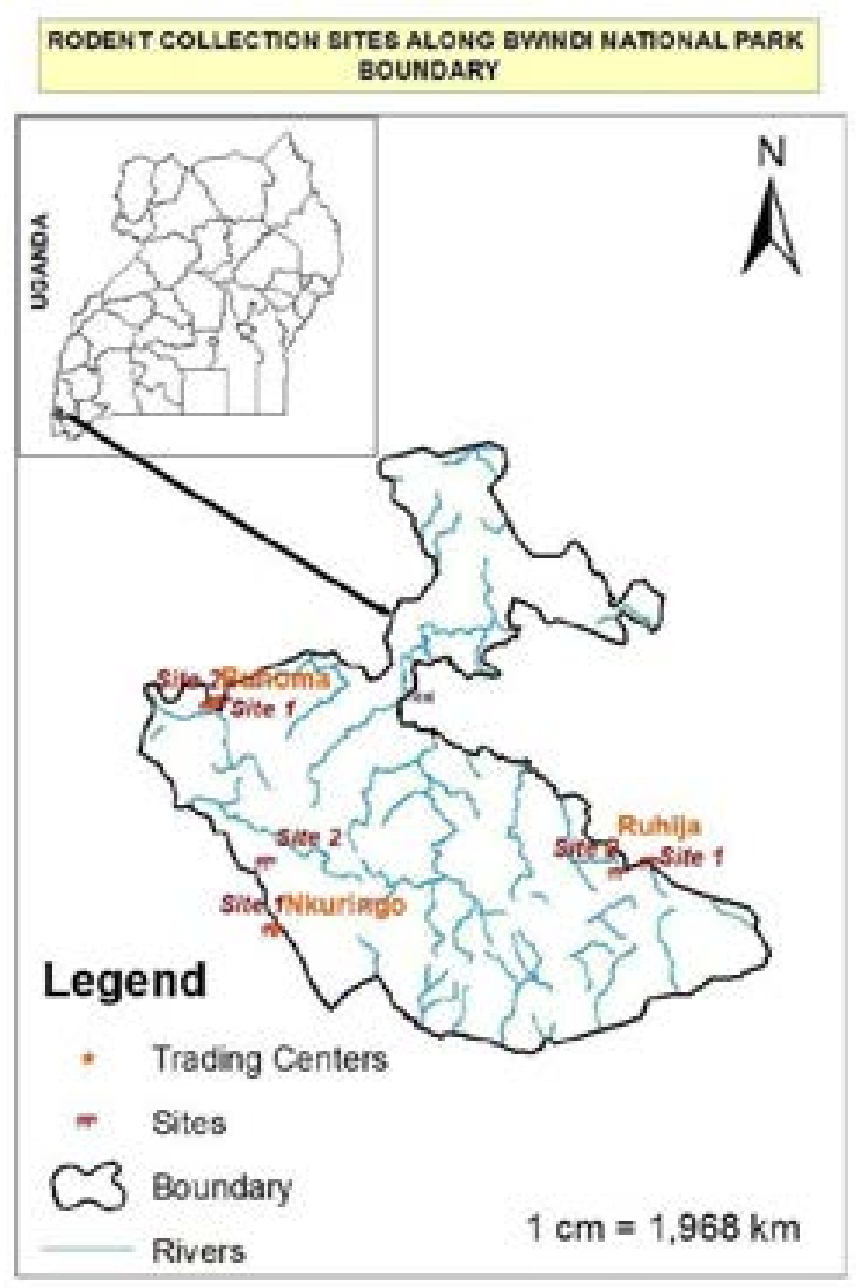

Figure 1: A map showing Bwindi Impenetrable National Park and the villages sampled. 


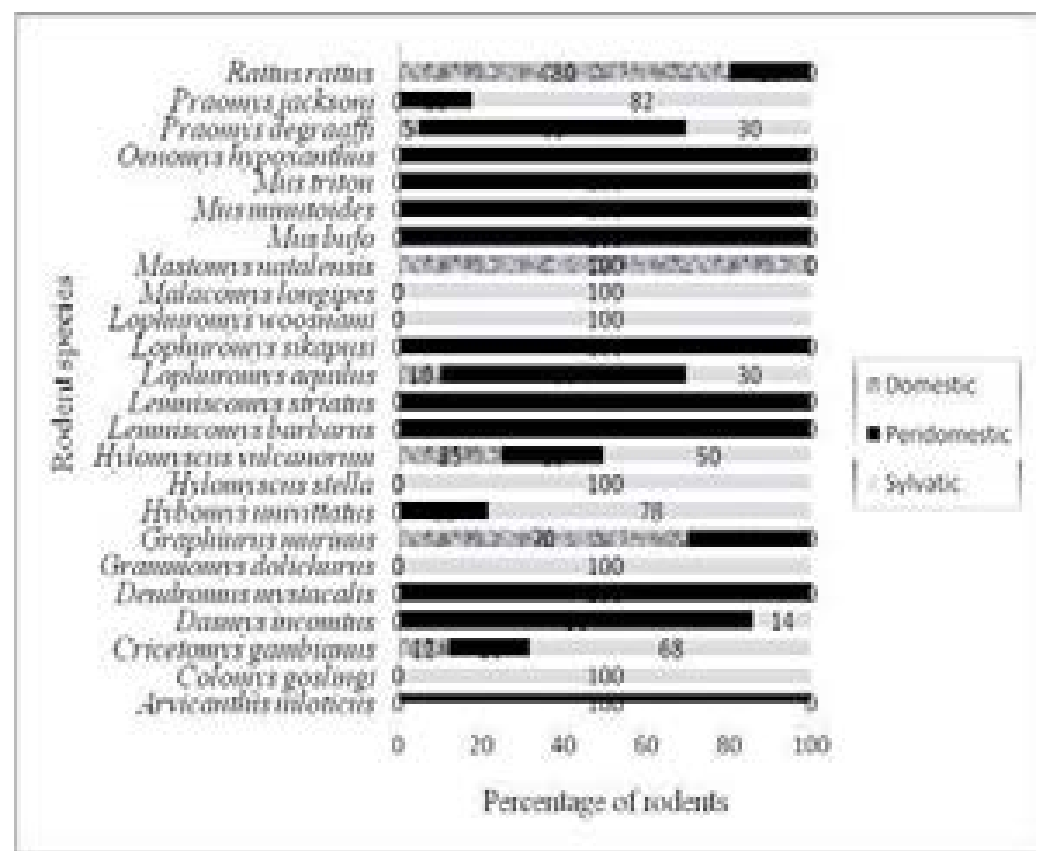

Figure 2: Proportions of each rodent species in domestic, peridomestic and sylvatic environments.

dents out of 249 resulting into an overall prevalence of recorded among fleas ( 9 species) followed by mites (5 $35.3 \%$. The highest ectoparasite species diversity was species) and ticks ( 2 species) (Tables $1 \& 2)$.

Table 1: Infestation of rodents with fleas in different study villages

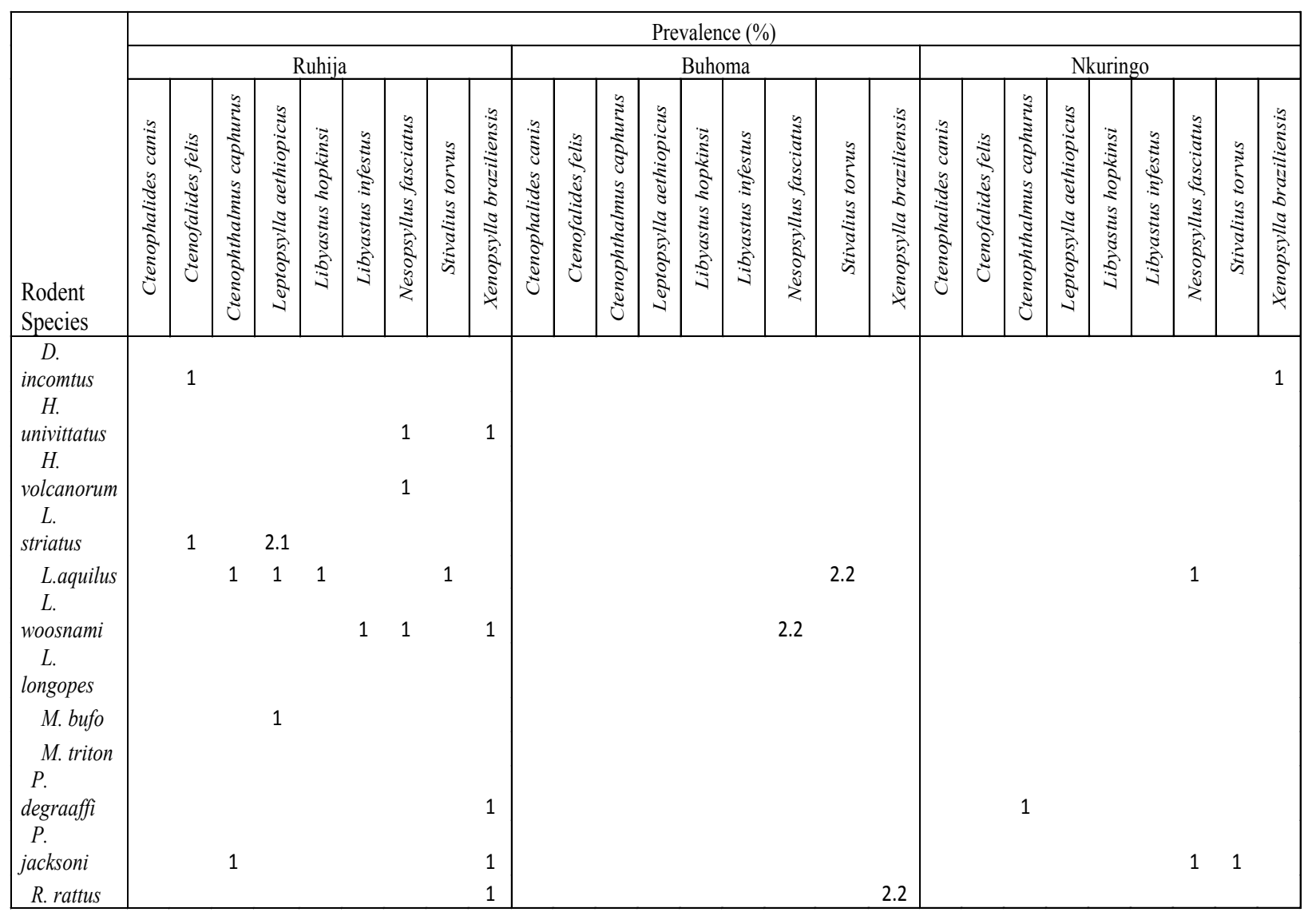


Table 2: Infestation of rodents with mites in the different study villages

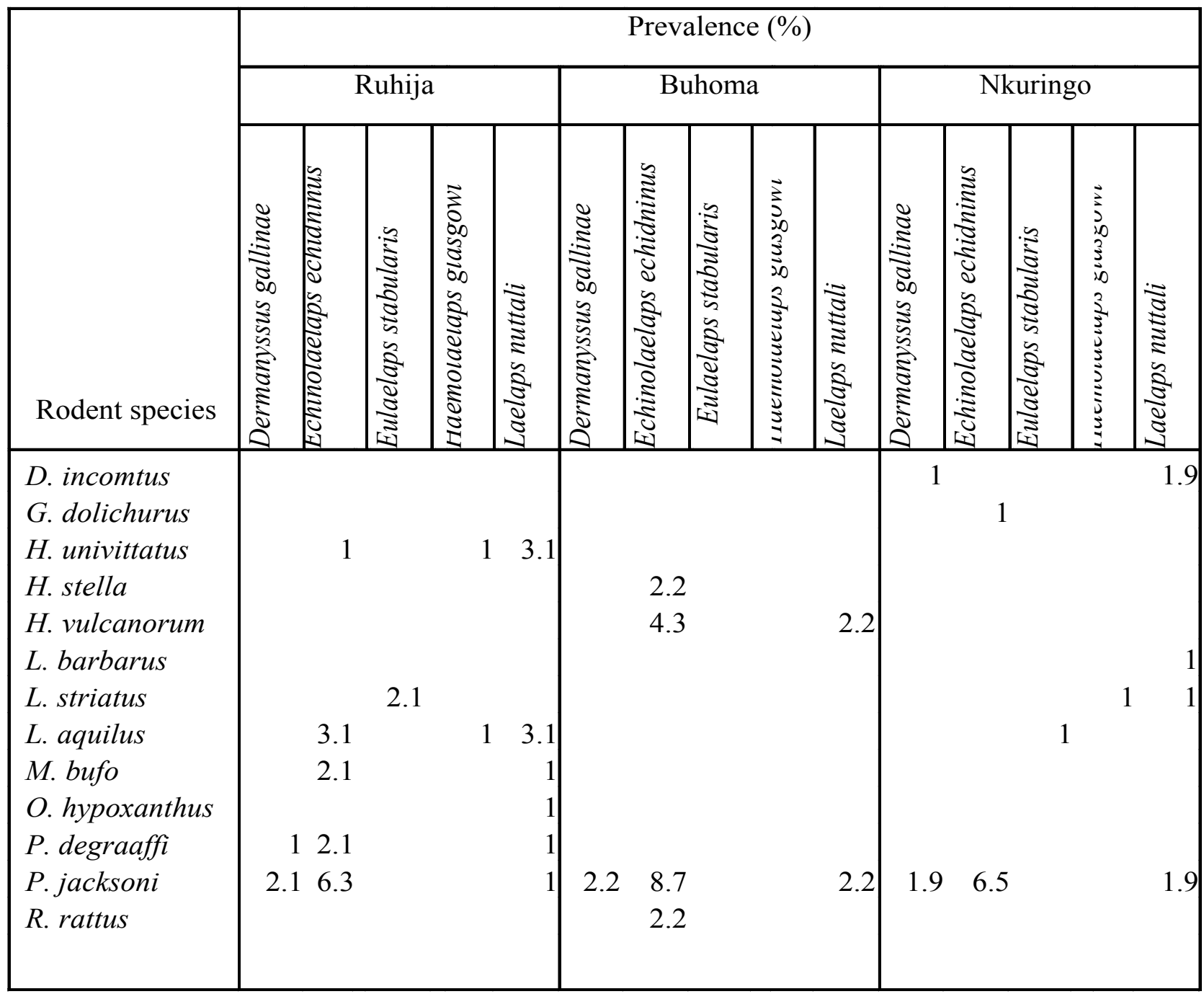

The number of infested rodents was significantly different among the study villages (Chi-square $=19.595, \mathrm{df}=2$, $\mathrm{P}<0.05)$. Rodents in Ruhija were most infested $(49 / 96$, $51 \%$ ) followed by those in Buhoma and then Nkuringo (15/46, 32.8 and 28/107, 26.2\% respectively). Praomys jacksoni rodents were most infested with a prevalence of $84.6 \%$ followed by Lophuromys aquilus (55.2\%). The majority of the ectoparasites were mites $(n=203 ; 84.6 \%)$ being dominated by Echinolaelaps echidninus (112, 55.2\%), followed by fleas $(\mathrm{n}=29 ; 12.1 \%)$ which were dominated by Stivalius torvus. Ticks, which constituted $0.8 \%$, had only two species Haemaphysalis leachi and Rhipicephalus lunulatus on P. jacksoni and Lemniscomys barbarous respectively. Ten ectoparasite-rodent associations were identified in which their specificity indices were above 50 . Ctenophalides canis, Haemaphysalis leachi, Leptopsylla aethiopicus and Rhipicephalus lunulatus were found exclusively on Lemniscomys striatus, Praomys jacksoni, Hybomys univittatus, Lophuromys woosnami and Lemniscomys barbarous respectively (Table 3). The relationship between rodent species abundance and ectoparasite abundance was not significant (rho $=0.447, \mathrm{n}=16, \mathrm{P}=0.083$ ) and the coefficient of determination was $19 \%$. 


\begin{tabular}{|c|c|c|c|c|c|c|c|c|c|c|c|c|c|c|c|c|}
\hline \multirow[b]{3}{*}{ Rodent species } & \multicolumn{16}{|c|}{ Specificity indices } \\
\hline & \multicolumn{9}{|c|}{ Fleas } & \multicolumn{5}{|c|}{ Mites } & \multicolumn{2}{|c|}{ Ticks } \\
\hline & 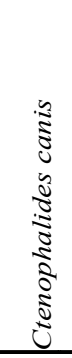 & 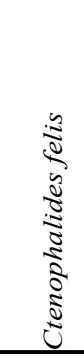 & 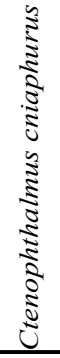 & 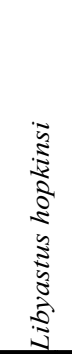 & 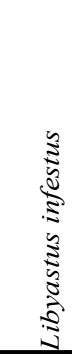 & 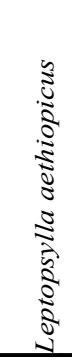 & 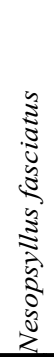 & 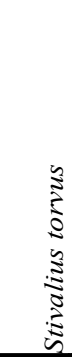 & 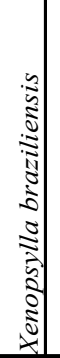 & 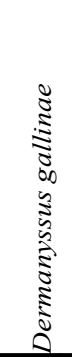 & 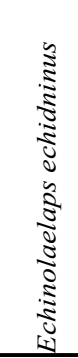 & 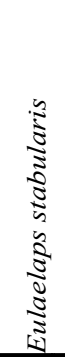 & 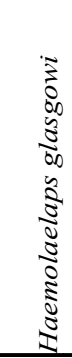 & $\begin{array}{l}-5 \\
5 \\
5 \\
\vdots \\
0 \\
5 \\
5 \\
5 \\
-1\end{array}$ & 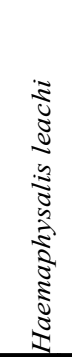 & 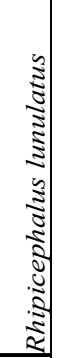 \\
\hline D. incomtus & 0 & 0 & 0 & 0 & 0 & 0 & 0 & 0 & 50 & 5.9 & 0 & 0 & 0 & 9.8 & 0 & 0 \\
\hline G. dolichurus & 0 & 0 & 0 & 0 & 0 & 0 & 0 & 0 & 0 & 0 & 0.9 & 0 & 0 & 0 & 0 & 0 \\
\hline H. univittatus & 0 & 0 & 0 & 0 & 16.7 & 100 & 0 & 28.6 & 0 & 0 & 4.5 & 0 & 62.5 & 14.8 & 0 & 0 \\
\hline H. stella & 0 & 0 & 0 & 0 & 0 & 0 & 0 & 0 & 0 & 0 & 5.4 & 0 & 0 & 0 & 0 & 0 \\
\hline H. vulcanorum & 0 & 0 & 0 & 0 & 33.3 & 0 & 0 & 0 & 0 & 0 & 8 & 0 & 0 & 9.8 & 0 & 0 \\
\hline L. barbarus & 0 & 0 & 0 & 0 & 0 & 0 & 0 & 0 & 0 & 0 & 0 & 0 & 0 & 4.9 & 0 & 100 \\
\hline L. striatus & 100 & 0 & 50 & 0 & 0 & 0 & 0 & 0 & 0 & 0 & 0 & 80 & 25 & 24.6 & 0 & 0 \\
\hline L. aquilus & 0 & 33.3 & 25 & 0 & 16.7 & 0 & 50 & 14.3 & 0 & 0 & 6.3 & 20 & 12.5 & 19.7 & 0 & 0 \\
\hline L. woosnami & 0 & 0 & 0 & 100 & 13.7 & 0 & 0 & 14.3 & 0 & 0 & 0 & 0 & 0 & 0 & 0 & 0 \\
\hline M. longipes & 0 & 0 & 0 & 0 & 0 & 0 & 25 & 0 & 0 & 0 & 0 & 0 & 0 & 0 & 0 & 0 \\
\hline M. bufo & 0 & 0 & 0 & 0 & 0 & 0 & 0 & 0 & 0 & 0 & 8.9 & 0 & 0 & 3.3 & 0 & 0 \\
\hline M. triton & 0 & 0 & 25 & 0 & 0 & 0 & 0 & 0 & 0 & 0 & 0 & 0 & 0 & 0 & 0 & 0 \\
\hline O. hypoxanthus & 0 & 0 & 0 & 0 & 0 & 0 & 0 & 0 & 0 & 0 & 0 & 0 & 0 & 3.3 & 0 & 0 \\
\hline P. degraaffi & 0 & 0 & 0 & 0 & 0 & 0 & 0 & 14.3 & 0 & 35.3 & 6.3 & 0 & 0 & 1.6 & 0 & 0 \\
\hline P. jacksoni & 0 & 66.7 & 0 & 0 & 16.7 & 0 & 25 & 14.3 & 0 & 58.8 & 54.4 & 0 & 0 & 8.2 & 100 & 0 \\
\hline R. rattus & 0 & 0 & 0 & 0 & 0 & 0 & 0 & 14.3 & 25 & 0 & 4.5 & 0 & 0 & 0 & 0 & 0 \\
\hline
\end{tabular}

Out of 249 rodents examined, 92 individuals belonging to 16 species were infected with endoparasites with an overall prevalence of $36.9 \%$. Rodents captured from Nkuringo were most infected (57/107, 53.3\%), followed by those from Buhoma (16/46, 34.8\%) and Ruhija (19/96, 19.5\%) (Table 4). The endoparasites collected from rodents included 4 nematodes of Nippostrongylus, Ascaris, Strongyloides and Trichuris species, 2 cestodes including Hymenolepis and Taenia species and a protozoan of Cryptosporidium species.
Majority of the rodent species (81.25\%) were infected with Nippostrongylus species. Among the 16 rodent species examined for endoparasites, Lophuromys aquilus and Praomys jacksoni were most infected with at least 5 and 4 genera of endoparasites respectively (Table 4). Majority of the rodent species (12 species) harboured 1 or 2 endoparasite genera, 2 harboured 3 , while at most 1 harboured 4 or 5 . The prevalence of endoparasites among rodents in the three villages was significantly different $($ Chi-square $=30.305, \mathrm{df}=2, \mathrm{P}<0.05)$. 
Table 4: Natural infection of rodents with endoparasites.

\begin{tabular}{|c|c|c|c|c|c|}
\hline \multirow{3}{*}{$\begin{array}{l}\text { Species of } \\
\text { rodent }\end{array}$} & \multirow[b]{3}{*}{ Endoparasite } & Ruhija & Buhoma & Nkuringo & Total \\
\hline & & $\mathrm{N}=96$ & $\mathrm{~N}=46$ & $\mathrm{~N}=107$ & $\mathrm{~N}=249$ \\
\hline & & $\mathrm{P( \% )}$ & $\mathrm{P}(\%)$ & $\mathrm{P}(\%)$ & $\mathrm{P}(\%)$ \\
\hline \multirow[t]{2}{*}{ L. woosnami } & Cryptosporidium sp. & 1 & 0 & 0.9 & 0.8 \\
\hline & Strongyloide sp. & 2.1 & 0 & 0 & 0.8 \\
\hline \multirow[t]{5}{*}{ L. aquilus } & Cryptosporidium sp. & 5.2 & 2.2 & 5.6 & 4.8 \\
\hline & Nippostongylus sp & 0 & 0 & 0.9 & 0.4 \\
\hline & Hymenolepis sp. & 1 & 0 & 0 & 0.4 \\
\hline & Strongyloide sp. & 1 & 0 & 0 & 0.4 \\
\hline & Ascaris sp. & 1 & 0 & 0.9 & 0.8 \\
\hline \multirow[t]{4}{*}{ P. jacksoni } & Crytosporidium sp. & 2.1 & 4.3 & 3.7 & 3.2 \\
\hline & Nippostongylus sp & $\beta .1$ & 0 & 1.9 & 2 \\
\hline & Hymenolepis sp. & 1 & 0 & 0 & 0.4 \\
\hline & Trichuris sp. & 0 & 0 & 1.9 & 0.8 \\
\hline \multirow[t]{3}{*}{ M. longipes } & Cryptosporidium sp. & 0 & 4.3 & 0.9 & 1.2 \\
\hline & Nippostongylus sp & 0 & 13 & 0.9 & 2.8 \\
\hline & Trichuris sp. & 0 & 2.2 & 0.9 & 0.8 \\
\hline \multirow[t]{3}{*}{ M. bufo } & Cryptosporidium sp. & 0 & 0 & 3.7 & 1.6 \\
\hline & Nippostongylus sp & 1 & 0 & 2.8 & 1.6 \\
\hline & Hymenolepis sp. & 0 & 0 & 0.9 & 0.4 \\
\hline \multirow[t]{2}{*}{ L. striatus } & Cryptosporidum sp. & 0 & 0 & 1.9 & 0.8 \\
\hline & Nippostongylus sp. & 1 & 0 & 3.7 & 2 \\
\hline \multirow[t]{2}{*}{ C. gambianus } & Cryptospridium sp. & 0 & 2.2 & 0.9 & 0.8 \\
\hline & Nippostongylus sp. & 0 & 4.3 & 1.9 & 1.6 \\
\hline \multirow[t]{2}{*}{ O. hypoxanthus } & Cryptosporidium sp. & 0 & 0 & 0.9 & 0.4 \\
\hline & Nippostongylus sp. & 0 & 0 & 1.9 & 0.8 \\
\hline \multirow[t]{2}{*}{ D. incomtus } & Cryptosporidium sp. & 0 & 0 & 0.9 & 0.4 \\
\hline & Nippostongylus sp. & 0 & 0 & 3.7 & 1.6 \\
\hline \multirow[t]{2}{*}{ G. dolichurus } & Cryptosporidium sp. & 0 & 0 & 0.9 & 0.4 \\
\hline & Nippostongylus sp. & 0 & 0 & 1.9 & 0.8 \\
\hline \multirow[t]{2}{*}{ M. triton } & Cryptosporidium sp. & 0 & 0 & 0.9 & 0.4 \\
\hline & Nippostongylus sp. & 0 & 0 & 0.9 & 0.4 \\
\hline A. niloticus & Taenia sp. & 0 & 0 & 0.9 & 0.4 \\
\hline H. stella & Nippostongylus sp. & 0 & 0 & 0.9 & 0.4 \\
\hline H. vulcanorum & Nippostongylus sp. & 0 & 0 & 0.9 & 0.4 \\
\hline L. barbarus & Nippostongylus sp. & 0 & 0 & 2.8 & 1.2 \\
\hline R. rattus & Cryptosporidium sp. & 0 & 2.2 & 0.9 & 0.8 \\
\hline Total & & 19.5 & 34.7 & 52.7 & 36.8 \\
\hline
\end{tabular}

$\mathrm{N}=$ Number of rodents examined for parasites; $\mathrm{P}(\%)=$ Prevalence of infection

\section{Discussion}

All rodent species recorded in this study are wide spread in East Africa and largely belonged to the family Muridae. African rodents belonging to family Muridae are reported to be concentrated in savannas and forests south of the sub desert zone of Sahara ${ }^{24}$ of which Bwindi is not an exception. These results were similar to those of other studies conducted in mountains of Elgon and Kilimanjaro ${ }^{24,25}$. Majority of the rodents were trapped from peridomestic environments because of the copious food resources readily available in such environments. Comparable findings were also reported by Kia et al and Jittapalapong et al in Ahvaz South West Iran and Thailand respectively. This suggests a high chance of parasite exchange among the rodents, human community and wildlife, since maximum interactions are anticipated in the peridomestic zones, especially in the resource utilisation zones and agricultural areas around Bwindi. In the resource utilisation zones and agricultural areas, humans, wildlife and rodents share the same space, the farmers working during the day and the rodents looking for food from dusk to dawn. Therefore, by spreading pathogens along their tracks, for instance through urine, rodents caindirectly transmit many disease-causing agents to humans ${ }^{4}$.

The predominance of acarina ectoparasites on rodents in this study rhymes with the findings ${ }^{26}$ in Africa and ${ }^{27}$, ${ }^{28}$ outside Africa. However, there was no link between elevation and ectoparasite abundance. This implied a limited effect of elevation on rodent's infestation with parasites. However, rodent's morphological, biological and ecological factors have been suggested by Lareschi to be associated with ectoparasite occurrence ${ }^{29}$. 
The hosting of high numbers and a wide range of ectoparasites by Praomys jacksoni and Lophuromys aquilus has also been observed elsewhere ${ }^{26}$ and is explained by the fact that the two rodents are capablef inhabiting a wide range of highland habitats and are not ecologically and geographically restricted ${ }^{30}$. This must have predisposed them to numerous ectoparasites in their natural habitats.

The dominance of Echinolaelaps echidninus on Praomys jacksoni was also recorded by ${ }^{27}$ since it's a well known wild rodent mite. This association presents a public health threat to humans and the wildlife. As interactions among humans, wildlife and the rodents increase, there is a likelihood for zoonoses spread since this mite has been reported to be a potential vector of Yersinia pestis, Coxiella burnetii, Orientia tsutsugamushi and Leptospira interrogan $^{31,32}$. The occurrence of Laelaps nuttali mite in large numbers but with low specificity for rodent hosts was also reported $b^{33,28}$. This implies that this mite is a generalist species ${ }^{28}$ capable of parasitising a wide range of rodent species, an aspect that favours its survival and perpetuates its spread. Since E. echidninus and L. nuttali are usually found on the same domestic rats ${ }^{29}$, these mites were found Rattus rattus in this study. Comparable findings were also reported by ${ }^{34}$.

The chicken mite, Darmanyssus gallinae documented in this study is a socio-economically important ectoparasite affecting poultry and many birds ${ }^{34}$. Although this parasitic mite is most commonly found on the skin of gallinaceous birds, the often close association between rodents and birds must result into many rodents becoming infested ${ }^{34}$. Consequently also the often close association between humans and rodents must result into many humans becoming infested. Such interactions among infested rodents, wildlife and humans pose a potential health threat to the human and wildlife communities in and around Bwindi; where numerous pathogens carried by $D$. gallinae may be shared.

Eulaelaps stabularia and Haemolaelaps glasgowi mites recorded on peridomestic rodent species in this study are common associates of vertebrate nests ${ }^{35}$. Thoccurrence of these mites on peridomestic rodents was also reported by Durden and Page. These mite species have been suspected to be vectors of many pathogens that cause epidemic diseases, including: Endemic Hemorrhagic Fever (EHF), forest encephalitis, lymphocytic chroriomeningitis, Query fever, North Asian tick borne typhus and tularemia ${ }^{31,32}$.
The incidence of Haemaphysalis leachi and Rhipicephalus lunulatus ticks on specific rodent species was also documented by Oguge et al. and Changbunjong ${ }^{26,28}$. These species are well known one-host ticks, with all stages that must be able to feed on the same species of host ${ }^{36}$. H. leachi has been reported to be a prominent transmitter of the protozoan Babesia canis, a causative agent of babesiosis in dogs and the bacterium Rickettsia conorii that causes typhus to humans ${ }^{36}$.

All the flea species documented in this study posed a serious public and veterinary health threat to human and wildlife because majority of them have been reported to be vectors of pathogens. This socio-economic importance of fleas has also been reported by Oguge et al and Amatre et al. ${ }^{26,37}$. The incidence of Ctenophthalmus cabirus, Ctenophalides canis and Xenopsylla braziliensis fleas on Lemniscomys striatus and Rattus rattus rodents was not surprising because the same species have been found in peridomestic rodent species ${ }^{37}$. Since these fleas have been reported to be important enzootic vectors of Yersinia pestis interactions between fleas infested rodents and humans are likely to enhance the spread of Plague within the communities around the national park ${ }^{6}$.

The occurrence of Nesopsyllus fasciatus on a cosmopolitan rodent species Lophuromys aquilus presents a greater health threat because it puts both humans and wildlife at risk. N. fasciatus fleas have been reported to be vectors of Salmonella bacteria that cause salmonellosis ${ }^{38}$.

The endoparasites prevalence in this study was lower than that reported elsewhere in Africa ${ }^{26,37}$ possibly because the studies were conducted in different agro-ecological zones. Majority of the rodents were captured from forested areas, where the main source of food was pasture which might have been contaminated with human, domestic and wild animal faeces ${ }^{39}$.

The high endoparasites prevalence for Lophuromys aquilus and Praomys jacksoni was not surprising because the two rodent species were the most abundant and are not ecologically and geographically restricted, as also explained by ${ }^{30}$. This might have predisposed them to numerous endoparasites in their habitats.

The endoparasite genera that were recorded in this study are all known to occur in domestic, peridomestic and sylvatic rodent species as also documented by Kataranovski et al. The dominance of Nippostrongylus spp on wild rodents was also reported by Waugh et al and Coomansingh et al. The presence of Cryptosporidium 
spp on rodents suggests a great health threat to humans and wildlife especially the critically endangered Mountain Gorillas; since C. parvum has been already reported to occur in gorillas of Bwindi by Nizeyi et al. Other endoparasites of Ascaris spp, Strongyloides spp and Trichuris spp that were collected from rodents in this study have also been reported to occur among people living around Bwindi and its wildlife ${ }^{45}, 46,47$. These findings reveal that rodents in and around Bwindi are potential reservoirs of many endoparasites some of which may be causative agents of zoonoses.

\section{Conclusion}

Rodents captured along Bwindi boundary were found to be parasitized by a wide range of ecto and endoparasites. Some of these endoparasites are known to cause zoonoses while majority of the ectoparasites are vectors of pathogens, some of which are potential causative agents of zoonoses. This implies that these rodents can play an important role as potential reservoirs of these endoparasites and hosts of the ectoparasites, an aspect that possess a greahealth threat to the human community around Bwindi and its wildlife. It is therefore imperative that high priority be given to research and development of effective integrated rodent management programs against domestic, peridomestic and sylvatic rodent species to reduce chances of parasite transmission.

\section{Acknowledgements}

In particular, we would like to thank MacArthur Foundation (Grant No. 19722) to Wildlife Conservation Society and the Institute of Tropical Forest Conservation for funding this study. Uganda Wildlife Authority granted us permission to carry out the study in Bwindi Impenetrable National Park.

\section{References}

1. Barrett A. Vector and Rodent-borne Diseases in Europe and North America: Distribution, Public Health Burden and Control. Emerging Infectious Diseases 2007; 13(8): 1278. doi: 10.3201/eid1308.070626.

2. Wilson DE, Reeder DM. Mammalian species of the world: a taxonomic and geographical reference. 3rd ed. Baltimore: John Hopkin University Press, 2005

3. Jittapalapong S, Herbreteau V, Hugot JP. Relationship of parasites and pathogens diversity to rodents in Thailand. Kasetsart J Nat Sci 2009; 43: 106-17. Available from: http:// kasetsartjnatsci.kasetsart.org

4. Eisen RJ, Enscore RE, Atiku LA, Zielinski-Gut- ierrez E, Mpanga JT, Kajik E, et al. Evidence that rodent control strategies ought to be improved to enhance food security and reduce the risk of rodent-borne illnesses within subsistence farming villages in the plague-endemic West Nile region, Uganda. Int J Pest Manag 2013; 59(4):259-270. doi: 10.1080/09670874.2013.845321

5. Imvithaya A, Warachit P, Naigowit P, Jenjittikul M, Pattamadilok S, Wootta W, et al. Survey of Host Reservoir of Rodent-Borne Diseases in Endemic Areas, Thailand 1999. serovars in rodents and shrews trapped in low and high endemic areas in Thailand. J. Health Sciences (Thai) 2001; 10: 526-532 PubMed .

6. Eisen RJ, MacMillan K, Atiku LA, Mpanga JT, Zielinski-Gutierrez E, Graham CB, et al. Identification of Risk Factors for Plague in the West Nile Region of Uganda. Am. J. Trop. Med. Hyg 2014; 90(6): 1047-1058. doi: 10.4269/ajtmh.14-0035.

7. Raharivolona BM, Ganzhone JU, Gastrointestinal parasite infection of the gray mouse lemur (Microcebus murinus) in the littoral forest of Mandena Madagasca: effects of forest fragmentation and degradation. Mad Cons Dev (2009), 4(2): 103-112. doi:10,4314/mcd. v4i2.48650

8. Levett PN. Leptospirosis. Clin Microbiol Rev 2001; 14(2): 296-326. doi: 10.1128/CMR.14.2.296326.2001

9. McCall PJ, Hume JC, Motshegwa K, Pignatelli P, Talbert A. Does tick-borne relapsing fever have an animal reservoir in East Africa? Vector Borne Zoonotic Dis 2004; 7(4): 659-666. doi. 10.1089/vbz.2007.0151

10. Yokota M, Morshed MG, Nakazawa T, Konishi H. Protective activity of Borrelia duttonii-specific immunoglobulin subclasses in mice. J Med Micro 1997; 46(8):675-680, doi: 10.1099/00222615-46-8-675

11. Diatta G, Souidi Y, Granjon L, Arnathau C, Durand P. Epidemiology of Tick-Borne Borreliosis in Morocco. PLoS Negl Trop Dis 2012; 6(9): e1810. doi:10.1371/journal.pntd.0001810

12. Adams HR, Sleeman J, Rwego I, New JC. Self-reported medical history survey of humans as a measure of health risks to chimpanzees (Pan troglodytes schweinfurthii) of Kibale National Park. Oryx 2001; 35(4): 308-312. doi:10.1046/j.1365-3008.2001.00194.x 13. FAO. Community-based enterprise development for conservation of biodiversity in Bwindi World Heritage Site, Kampala: Kampala. Forest Policy and Institutions, 2005.

14. Blomley T. Natural resource conflict management: the case of Bwindi Impenetrable and Mgahinga Gorilla National Park, South western Uganda. Kampala: CARE international (Uganda), 2008. 
15. Goldsmith ML. Effects of Ecotourism on Behavioral Ecology of Bwindi Gorillas, Uganda: Preliminary Results. American Journal of Physical Anthropology 2000; 30: 161

16. Gilardi KV, Gillespie TR, Leendertz FH, Macfie EJ, Travis DA, Whittier CA, et al. Best Practice: Guidelines for Health Monitoring and Disease Control in Great Ape Populations. Gland, Switzerland: IUCN Species Survival Commission Primate Specialist Group 56, 2015. Dol:10.2305/IUCN.CH.2015.SSC-OP.56.en

17. Rwego IB, Isabirye-Basuta G, Gillepsie TR, Goldberg TL. Gastrointestinal bacterial transmission among Humans, Mountain Gorillas and Livestock in Bwindi Impenetrable National Park, Uganda. Conservation Biology 2008; 22(6): 1600-1607. doi:10.1111/j.15231739.2006.01018.x

18. Kityo RL. Small mammals of the Ssese Islands. MSc. Thesis. Kampala: Makerere University,1993.

19. Jaunbauere G, Salmane I, Spungis V. Occurrence of bat ectoparasites in Latvia. Latvijas Entomologs 2008; 45: 38-42.

20. Kia E B, Moghddas H, Vabandest A, Akhavan A. Ectoparasites of rodents captured in Bandar Abbas, southern Iran, Iranian. Arthropod Borne Dis 2009; 3(2): 44-49.

21. USAID PREDICT project. Guide for safe animal capture for sampling. Davis. University of California, 2009.

22. Dryden MW, Payne PA, Ridley R, Smith V. Comparisons of common fecal flotation techniques for recovery of parasite eggs and oocysts. Veterinary Therapeutics research in Applied Veterinary Medicine 2005; 6(1): 15-28.

23. Marshall AG. The ecology of ectoparasitic insects. New York. Academic Press, 1981.

24. Clausnitzer V, Kityo R. Altitudinal distribution of rodents (Muridae and Gliridae) on Mt. Elgon, Uganda. Tropical Zoology 2001; 14(1): 95-118. doi:10.1080/03 946975.2001.10531145

25. Mulungu LS, Makundi RH, Massawe AW, Machangu RS, Mbije NE. Diversity and distribution of rodent and shrew species associated with variations in altitude on Mount Kilijanjaro, Tanzania. Mammalia 2008; 72(3): 178-185. doi10.1515/MAMM.2008.021

26. Oguge NO, Durben LA, Keirans JE, Balami HD, Schwan TG. Ectoparasites (sucking lice, fleas and ticks) of small mammals in south eastern Kenya. Medical and Veterinary Entomology 2009; 23(4): 387-392. doi:10.1111/j.1365-2915.2009.0082.x

27. Wei L, Wang X, Wang C, He H. A survey of ectoparasites from wild rodents and Anourosorex squamipes in Sichuan province, south western China. Journal of Ecology and the Natural Environment 2010; 2(8): 160166.

28. Changbunjong T, Weluwanarak T, Chamsai T, Sendwisai P, Ngamloephochit S, Suwanpakdee S, et al. Occurance of ectoparasites on rodents in Sukhothai province, Northern Thailand. South East Asia. J. Trop. Med. Public Health 2010; 41(6): 1324-1330.

29. Lareschi M. Ectoparasite occurance associated with males and females of wild rodents, Oligoryzomys flavescene (Waterhouse) and Akodon azarae (Fischer) (Rodentia: Cricetidae: Sigmodontinae) in the Punta Lara wetlands, Argentina. Neotropical Entomology 2010; 39(5): 818-822. doi:10.1590/S1519566X2010000500022

30. Clausnitzer V, Church S, Hutterer R. Habitat occurrence and feeding ecology of Crocidura mentis and Lophuromys flavopuntatus on Mt. Elgon, Uganda. Africa. J. Ecol 2003; 41(1): 1-8. doi:10.1046/j.13652028.2003.00386.x

31. Fang MY, Lin LH, Liu JW. Arthropod-borne infectious diseases, China. Beijing. Science and Medicine Military Publishing House, 2005.

32. Wen-ge D, Xian-guo G, Xing-yuan M, Tin-jun Q, Dian W. Ectoparasites of Eothanomys miletus in the focus of plague in Northwest Yunnan. Sichuan Journal of Zoology 2009; 28: 683-690.

33. Nieri-Bastos FA, Barros-Battestp DM, Linadi PM, Amuku M, Marcili A, Flavorito SE. et al. Ectoparasites of wild rodents from Parque Estadual Da Cantareira (Pedra Grand Nuclei) Sao Paulo, Brazil. Rev. Bras. Parasitol Vet, 2004; 13(1): 29-35.

34. Durden LA, Page BF. Ectoparasites of commensal rodents in Sulawesi Utara, Indonesia, with notes on species of medical importance. Med Vet Entomol 1991;. 5(1): 1-7. doi:10.1111/j.1365-2915.1991. tb00513.x

35. Lareschi M. The relationship of sex and ectoparasite infestation in the water rat Scapteromys aquaticus (Rodentia: Crecetidae) in La Plata, Argentina. Rev Biol Trop 2006; 54(2): 673-679.

36. Walker AR, Bouattour A, Camicas JL, Estrada-Pena A, Horak IG, Latif AA, et al. Ticks of domestic animals in Africa: a guide to identification of species. Edinburgh. Scotland, U.K. Bioscience Reports, 2003.

37. Amatre G, Babi N, Enscore RE, Ogen-Odoi A, Atiku LA, Akol A. et al. Flea diversity and infestation prevalence on rodents in a plague endemic region of Uganda. Am. J. Trop. Med. Hyg 2009; 81(4): 718-724. doi:10.4269/ajtmh.2009.09-0104 
38. Pham HV, Dang DT, Tran Minh NN, Nguyen ND, Nguyen TV. Correlates of environmental factors and human plague; an ecological study in Vietnam. International Journal of Epidemiology 2009; 38(6): 16341641. doi:10.1093/ije/dyp244

39. Abd el-Wahed MM, Salem GH, el-Assaly TM. The role of wild rats as a reservoir of some internal parasites in Qalyobia governorate. Journal of the Egyptian Society of Parasitology 1999; 29(2): 495-503.

40. Kataranovski DS, Vukicevic Radic OD, Kataranovski MV, Radovic DL, Mirkov II. Helminth fauna of Mus musculus Linnaeus, 1758, from the suburban area of Beigrade Serbia. Arch. Biol. Sci 2008; 60(4): 609617.

41. Waugh CA, Lindo JF, Foronda P, Santana MA, Morales JL, Robinson RD. Population distribution and zoonotic potential of gastrointestinal helminths of wild rats Rattus rattus and R. norvegicus from Jamaica. Jour nal of Parasitology 2006; 92(5): 1014-1018. doi:10.1645/ GE-795R1_1.

42. Coomansingh C, Pinckney RD, Bhaiyat MI, Chikweto A, Bitner S, Baffa A, et al. Prevalence of endoparasites in wild rats in Grenada. West Indian Veterinary Journal 2009; 9(1): 17-21.
43. Nizeyi JB, Cranfield MR, Graczyk TK. Cattle near the Bwindi Impenetrable National Park, Uganda, as a reservoir of Cryptosporidium parvum and Giardia duodenalis for local community and free-ranging gorillas. Parasitol Res 2002; 88(4): 380385.

doi:10.1007/s00436-001-0543-x

44. Nizeyi JB, Sebunya D, Dasilva AJ, Cranfield MR, Pieniazek NJ, Graczyk TK. Cryptosporidiosis in people sharing habitats with free-ranging mountain gorillas (Gorilla gorilla beringei), Uganda. Am J Trop Med Hyg 2002;. 66(4): 442- 444. doi:10.4269/ajtmh.2002.66.442 45. Ashford RW, Reid GDF, Butynski TM. The intestinal faunas of man and mountain gorillas in a shared habitat. Ann Trop Med Parasitol 1990. 84(4): 337-340. doi $: 10.1080 / 00034983.1990 .11812477$

46. Kalema GRNN. Epidemiology of the intestinal parasite burden of mountain gorillas in Bwindi Impenetrable Forest national Park. British Veterinary Zoological Society Newsletter 1995; 14: 4-6.

47. Rothman JM, Bowman DD, Kalema-Zikusoka G, Nkurunungi JB. The parasites of the gorillas in Bwindi Impenetrable National Park, Uganda. In: Paterson J, Reynolds V, Notman H, Newton-Fisher N (eds) Primates of western Uganda. Kluwer, Dordrecht, 2004. 